\title{
Characterization of Immunophenotypic Aberrancies with Respect to Common Fusion Transcripts in B-Cell Precursor Acute Lymphoblastic Leukemia: A Report of 986 Indian Patients
}

\author{
Prekürsör B-Akut Lenfoblastik Lösemide Yaygın Füzyon Transkriptlerine Göre \\ İmmünofenotipik Anormalliklerin Karakterizasyonu: 986 Hintli Hastayı İçeren Bir Rapor
}

\begin{abstract}
(D) Dikshat Gopal Gupta1, (D) Neelam Varma1, (D) Shano Naseem¹, (D) Man Updesh Singh Sachdeva1, (D) Parveen Bose1, (D) Jogeshwar Binota1, (D) Ashish Kumar2, (D) Minakshi Gupta1, (D) Palak Rana1, (D) Preeti Sonam¹, (D) Pankaj Malhotra1, (D) Amita Trehan1, (D) Alka Khadwal1, (D) Subhash Varma1
\end{abstract}

1 Postgraduate Institute of Medical Education and Research, Chandigarh, India

2 International Centre for Genetic Engineering and Biotechnology, New Delhi, India

\section{Abstract}

Objective: Based on the immunophenotype, acute lymphoblastic leukemia (ALL) can be categorized into B-cell or T-cell lineages. B-cell precursor ALL (BCP-ALL) cases show various genetic/molecular abnormalities, and varying frequencies of chimeric fusion transcripts in BCP-ALL cases are reported from different parts of the world. We studied the immunophenotypic aberrancy profiles of a large number of BCP-ALL cases with respect to various common chimeric fusion transcripts.

Materials and Methods: Flow cytometric immunophenotyping and multiplex reverse-transcription polymerase chain reaction assays were performed for 986 BCP-ALL cases.

Results: Among 986 BCP-ALL cases, the incidence of various fusion transcripts was $38.36 \%$ in adult cases and $20.68 \%$ in pediatric cases. Adult BCP-ALL patients with $\mathrm{t}(9 ; 22)(B C R-A B L 1)$ fusion transcripts and expression of aberrant myeloid markers were significantly older at presentation $(p=0.0218)$ with male preponderance $(p=0.0246)$ compared to those without aberrant myeloid expression. In pediatric patients with the $t(12 ; 21)(E T V 6-R U N X 1)$ chimeric fusion transcript, aberrant expression of CD13 was observed in $39.13 \%$, CD33 in $36.95 \%$, and CD117 in 8.69\% of patients, respectively. Pediatric BCPALL patients with the ETV6-RUNX1 fusion transcript and expression of aberrant myeloid markers were not significantly different compared to those without with respect to demographic and clinical/hematological characteristics ( $p=0.5955)$. Aberrant myeloid markers were rarely or never expressed in pediatric and adult BCP-ALL patients with the $\mathrm{t}(4 ; 11)(K T M 2 A-A F 4)$ and $\mathrm{t}(1 ; 19)(T C F 3-P B X 1)$ fusion transcripts.

Conclusion: Aberrant myeloid markers were frequently expressed among BCP-ALL patients with the $\mathrm{t}(9 ; 22)(B C R-A B L 1)$ and $t(12 ; 21)$ (ETV6-RUNX1) fusion transcripts. However, BCP-ALL patients with

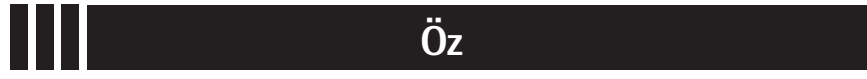

Amaç: Akut lenfoblastik lösemi (ALL), immünofenotipe dayalı olarak, B-hücre veya T-hücre kökenli olarak kategorize edilebilir. B-hücre prekürsör ALL (BCP-ALL) olguları çeşitli genetik/moleküler anormallikler gösterir ve BCP-ALL olgularındaki kimerik füzyon transkriptlerinin değişik frekansları dünyanın farklı yerlerinden rapor edilmiştir. Çok sayıda BCP-ALL olgusunun ortak yaygın kimerik füzyon transkriptlerine göre immünofenotipik anormallik profillerini inceledik.

Gereç ve Yöntemler: 986 BCP-ALL olgusu için akım sitometrik immünofenotipleme ve multipleks ters-transkripsiyon polimeraz zincir reaksiyonu çalışmaları yapıldı.

Bulgular: 986 BCP-ALL olgusu arasında çeşitli füzyon transkriptlerinin insidansı yetişkin olgularda $\% 38,36$ ve pediatrik olgularda $\% 20$ ,68 idi. T(9;22)(BCR-ABL1) füzyon transkripti ve anormal myeloid belirteç ifadesi olan yetişkin BCP-ALL hastaları, anormal myeloid ifadesi olmayanlarla karşılaştırıldığında anlamlı olarak daha yaşlıydı $(p=0,0218)$ ve erkek çoğunluğu vardı $(p=0,0246)$. t(12;21)(ETV6RUNX1) kimerik füzyon transkripti olan pediyatrik hastalarda, sırasıyla anormallik CD13 ifadesi \%39,13, CD33 \%36,95 ve CD117\%8,69 hastada gözlendi. ETV6-RUNX1 füzyon transkripti ve anormal myeloid belirteç ifadesi olan pediatrik BCP-ALL hastaları, olmayanlara kıyasla demografik ve klinik/hematolojik özellikler açısından farklı değildi $(\mathrm{p}=0,5955) . \quad \mathrm{t}(4 ; 11)(K T M 2 A-A F 4)$ ve $\mathrm{t}(1 ; 19)(T C F 3-P B X 1)$ füzyon transkriptlerine sahip pediatrik ve yetişkin BCP-ALL hastalarında anormallik myeloid belirteçler nadiren veya hiç ifade edilmedi.

Sonuç: Anormallik myeloid belirteçler, $t(9 ; 22)(B C R-A B L 1)$ ve $\mathrm{t}(12 ; 21)(E T V 6-R U N X 1)$ füzyon transkriptleri olan BCP-ALL hastaları arasında sıklıkla ifade edilmişti. Bununla birlikte, $t(4 ; 11)($ KTM2A$A F 4)$ ve $\mathrm{t}(1 ; 19)(T C F 3-P B X 1)$ füzyon transkriptlerine sahip BCP-ALL

๑Copyright 2022 by Turkish Society of Hematology

Turkish Journal of Hematology, Published by Galenos Publishing House

口, Address for Correspondence/Yazışma Adresi: Neelam Varma, M.D., Postgraduate Institute of Medical Education 


\section{Abstract}

the $\mathrm{t}(4 ; 11)($ KTM2A-AF4) and $\mathrm{t}(1 ; 19)($ TCF3-PBX1) fusion transcripts rarely or never expressed aberrant myeloid markers. Aberrant myeloid CD markers can be used in predicting chimeric fusion transcripts at baseline so as to plan appropriate tyrosine kinase inhibitor therapy in cases of BCP-ALL with specific chimeric fusion transcripts. This study has delineated the relationship of chimeric fusion transcripts with the aberrant expression of myeloid markers in a large cohort of BCP-ALL cases.

Keywords: Acute leukemia, Acute lymphoblastic leukemias, Molecular biology, Molecular hematology, Neoplasia

\section{$\ddot{0} z$}

hastaları, anormallik myeloid belirteçleri nadiren veya hiç ifade etmemişti. Anormallik myeloid CD belirteçleri, spesifik kimerik füzyon transkriptleri olan BCP-ALL olgularında, başlangıçta kimerik füzyon transkriptlerini tahmin etmede ve böylece uygun tirozin kinaz inhibitör tedavisini planlamak için kullanılabilir. Bu çalışma, geniş bir BCP-ALL olgu kohortunda kimerik füzyon transkriptlerinin myeloid belirteçlerin anormal ifadesi ile ilişkisini tanımlamıştır.

Anahtar Sözcükler: Akut lösemi, Akut lenfoblastik lösemi, Moleküler biyoloji, Moleküler hematoloji, Neoplazi

\section{Introduction}

Acute lymphoblastic leukemia (ALL) is a blood disorder with uncontrolled clonal proliferation of lymphoblasts in the bone marrow, blood, and/or tissues. Based on flow cytometric immunophenotyping (FCM-IP), ALL can be classified as B-cell or T-cell lineage [1]. ALL is a genetically heterogeneous disease characterized by chromosomal rearrangements, structural variations, copy number variations, and sequence mutations $[2,3,4,5]$. Pediatric B-cell precursor ALL (BCP-ALL) cases are often associated with a number of cytogenetic/molecular rearrangements, including hyperdiploidy, hypodiploidy, $t(9 ; 22)$ (BCR-ABL1), $\quad \mathrm{t}(12 ; 21)(E T V 6-R U N X 1), \quad \mathrm{t}(4 ; 11)($ KTM2A-AF4), $\mathrm{t}(1 ; 19)(T C F 3-P B X 1)$, and rearrangement of the CRLF2 and $K M T 2 A$ genes. Different age groups have varying frequencies of these genetic subtypes. Hyperdiploidy ( $>50$ chromosomes) and $\mathrm{t}(12 ; 21)(E T V 6-R U N X 1)$ are observed less commonly in adults compared to pediatric cases and the incidence of Ph positivity increases with advancing age. Treatment outcomes of adult ALL patients are far inferior to those of pediatric ALL cases, possible reasons being the reduced incidence of cytogenetic/molecular abnormalities associated with favorable outcome (e.g., more frequent hyperdiploidy and ETV6-RUNX1 translocation in pediatric $A L L)$ and the rising incidence of $B C R-A B L 1$ positivity $[3,6,7]$. Authors around the globe have reported high incidences (7\%-34.4\%) of $\mathrm{t}(12 ; 21)(E T V 6-R U N X 1)$ and low incidences $(2 \%-11.9 \%)$ of $\mathrm{t}(9 ; 22)(B C R-A B L 1)$ in pediatric $\mathrm{B}-\mathrm{ALL}$ and high incidences $(3.2 \%-37 \%)$ of $\mathrm{t}(9 ; 22)(B C R-A B L 1)$ in adult B-ALL $[8,9$ $, 10,11,12,13,14,15,16,17,18,19,20,21]$. Few authors have studied B-ALL for immunophenotypic aberrancies, with reported expression of CD13 in 5.88\%-56.1\%, CD33 in 2.47\%-49\%, and CD117 in $0.68 \%-22 \%$ of cases $[18,22,23,24,25,26]$.

Earlier we reported our experience of detection of chimeric fusion transcripts in B-cell ALL [9] and immunophenotypic aberrancies in ALL [18] in two different sets of patients at different time points. The presence of aberrant myeloid-associated markers in B-ALLs might necessitate the search for poor prognostic parameters, e.g., $\mathrm{t}(9 ; 22)(B C R-A B L 1)$, which are likely to impact case management [27]. In the present study, we have tried to delineate the relationship between chimeric fusion transcripts and expression of aberrant myeloid-associated markers among 986 BCP-ALL cases. To date, few studies have addressed this issue, with much smaller numbers of patients harboring various fusion transcripts.

\section{Materials and Methods}

The present study was conducted in the Department of Hematology of the Postgraduate Institute of Medical Education and Research (PGIMER), Chandigarh, India. This study was approved by the Institutional Ethics Committee (No. INT/IEC/2017/191 dated August 23, 2017). In our institute, patients up to 12 years of age are managed by the pediatric hematology oncology unit of the department of pediatrics and the rest are managed by the adult hematology unit of the department of internal medicine. We examined 986 BCP-ALL cases, including 522 pediatric and 464 adult cases. Complete blood count (CBC), bone marrow (BM) examination, FCM-IP, and multiplex reverse-transcription polymerase chain reaction (RTPCR) assay were performed.

\section{Sample Collection}

Samples of 2-3 mL of aspirated BM and 3-5 mL of peripheral blood (PB) were collected in EDTA-coated vials after obtaining the signature of the patient or the patient's guardian on an informed consent form as approved by the Human Institutional Ethics Committee of PGIMER. PB samples were processed for various hematological tests, including $C B C$ and $P B$ film examination. Furthermore, May-Grunwald-Giemsa and cytochemical staining including myeloperoxidase and periodic acid-Schiff were performed on PB/BM smears. Finally, PB/BM samples were processed for FCM-IP and molecular diagnostic testing.

\section{Flow Cytometric Immunophenotyping (FCM-IP)}

After morphological assessment, $\mathrm{PB} / \mathrm{BM}$ samples were processed for FCM-IP to diagnose BCP-ALL cases according to the protocol 
standardized and practiced in the department [18], presently consisting of a panel of 42 monoclonal antibodies (Table 1). At least $1 \times 10^{6}$ events were acquired on a ten-color/twelveparameter flow cytometer (Navios EX, Beckman Coulter, Chino, (A, USA) and analyzed using Kaluza 2.1 software.

Briefly, the blasts were gated on a plot of CD45 versus side scatter (SS), with blasts mostly representing CD45-dim and SSlow events. Expression of B-lineage-associated markers (CD19, CD10, cytoplasmic CD79a, cytoplasmic CD22) and immaturityassociated markers (CD34, CD38, TdT) confirmed the presence of B-lineage blasts. Expression of myeloid lineage-associated markers including CD13, CD33, and CD117 was also noted. B-lineage blasts were considered to express aberrant myeloid markers if $>20 \%$ blasts showed positivity for the marker (Figure 1). In addition, absence of cytoplasmic anti-myeloperoxidase and cytoplasmic CD3 was noted to exclude mixed phenotypic acute leukemia.

\section{Multiplex RT-PCR for Chimeric Fusion Transcripts}

Total RNA was isolated using the commercially available OlAamp RNA Blood Mini Kit (OIAGEN, Hilden, Germany) according to the manufacturer's instructions, followed by NanoDrop quantification (Thermo Scientific, Waltham, MA, USA). Thereafter, cDNA was prepared from $1 \mu \mathrm{g}$ of RNA using a cDNA synthesis kit (Thermo Scientific). The quality of the cDNA was assessed by running $2 \%$ agarose gel electrophoresis for the PCR product of $\beta$-actin as the housekeeping gene. Finally, 1 $\mu \mathrm{g}$ of cDNA was used for multiplex RT-PCR assay with specific primers for various fusion transcripts according to the protocol followed in our department [28]. Details of primers for major and minor fusion transcripts are shown in Table 2.

\section{Statistical Analysis}

Data are represented as mean, median, and range in this study. The normality of the data was determined by Shapiro-Wilk test. For continuous variables and uniformly distributed data, the independent t-test was applied, and for non-uniformly distributed data, the Mann-Whitney U test was applied to rule out variability in the data. Statistical analysis was performed using GraphPad Prism 7.1 and values of $p<0.05$ were taken as significant.

\section{Results}

\section{Patients' Characteristics}

Among 986 BCP-ALL patients, 610 were male and 376 were female (male-to-female ratio: 1.62:1), with a median age of 11 years (minimum-maximum: 1-85 years). Males predominated significantly in both adult and pediatric groups. CBC results showed median hemoglobin $(\mathrm{Hb})$ of 7.8 (minimum-maximum: 2.4-15.5 g/dL), median total leukocyte count (TLC) of 12.4 (minimum-maximum: $0.3-576 \times 10^{9} / \mathrm{L}$ ), and median platelet

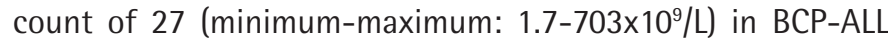
patients, as shown in Table 3. Hb and platelet counts were significantly lower while TLC was significantly higher in adults compared to the pediatric group $(p<0.0001)$.

\section{Multiplex RT-PCR Results}

Multiplex RT-PCR assays revealed recurrent genetic abnormalities in 38.36\% (178/464) adult and 20.68\% (108/522) pediatric BCPALL cases. The $B C R-A B L 1$ chimeric fusion transcript was observed in 31.68\% (147/464) adult and 7.08\% (37/522) pediatric ALL cases, being significantly more frequent in adults compared to children $(p<0.0001)$.

$B C R-A B L 1$ fusion transcripts result from the following breakpoints: a minor breakpoint (e1a2, p190 kDa), major

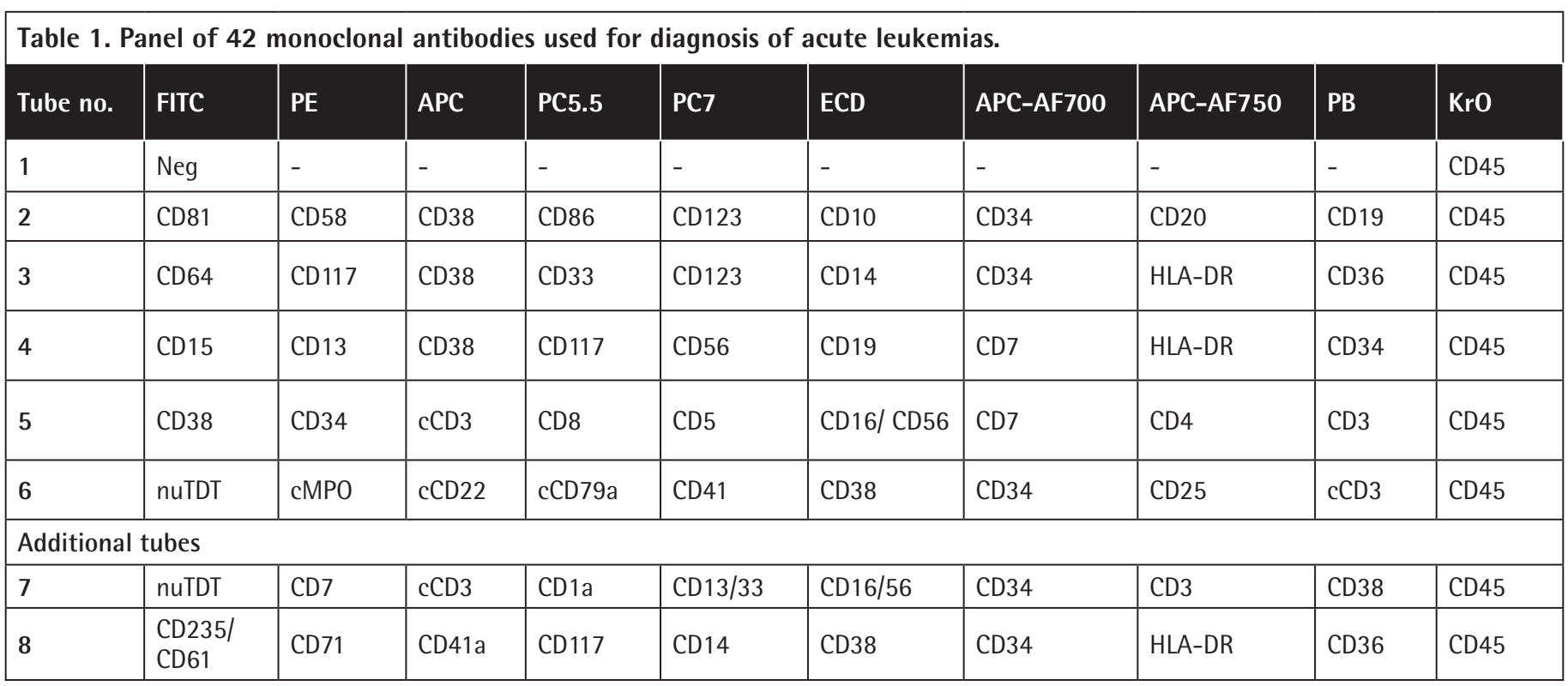


breakpoints (b2a2, p210 kDa; b3a2, p210 kDa), and a micro breakpoint (e19a2, p230 kDa). Among patients with BCR-ABL1 fusion transcripts, the minor (e1a2) transcript was observed in $46.93 \%(69 / 147)$ adult and 59.45\% (22/37) pediatric cases, a major (b2a2) transcript in 25.85\% (38/147) adult and 29.72\% (11/37) pediatric cases, and the other major (b3a2) transcript in $27.21 \%(40 / 147)$ adult and $10.81 \%(4 / 37)$ pediatric cases; no micro (e19a2) transcript was observed in this study. The e1a2 and b2a2 fusion transcripts were significantly more frequent in pediatric BCP-ALL cases, whereas the b3a2 fusion transcripts were significantly more frequent in adult BCP-ALL cases $(p<0.0001)$. The $t(4 ; 11)($ KTM2A-AF4) fusion transcript
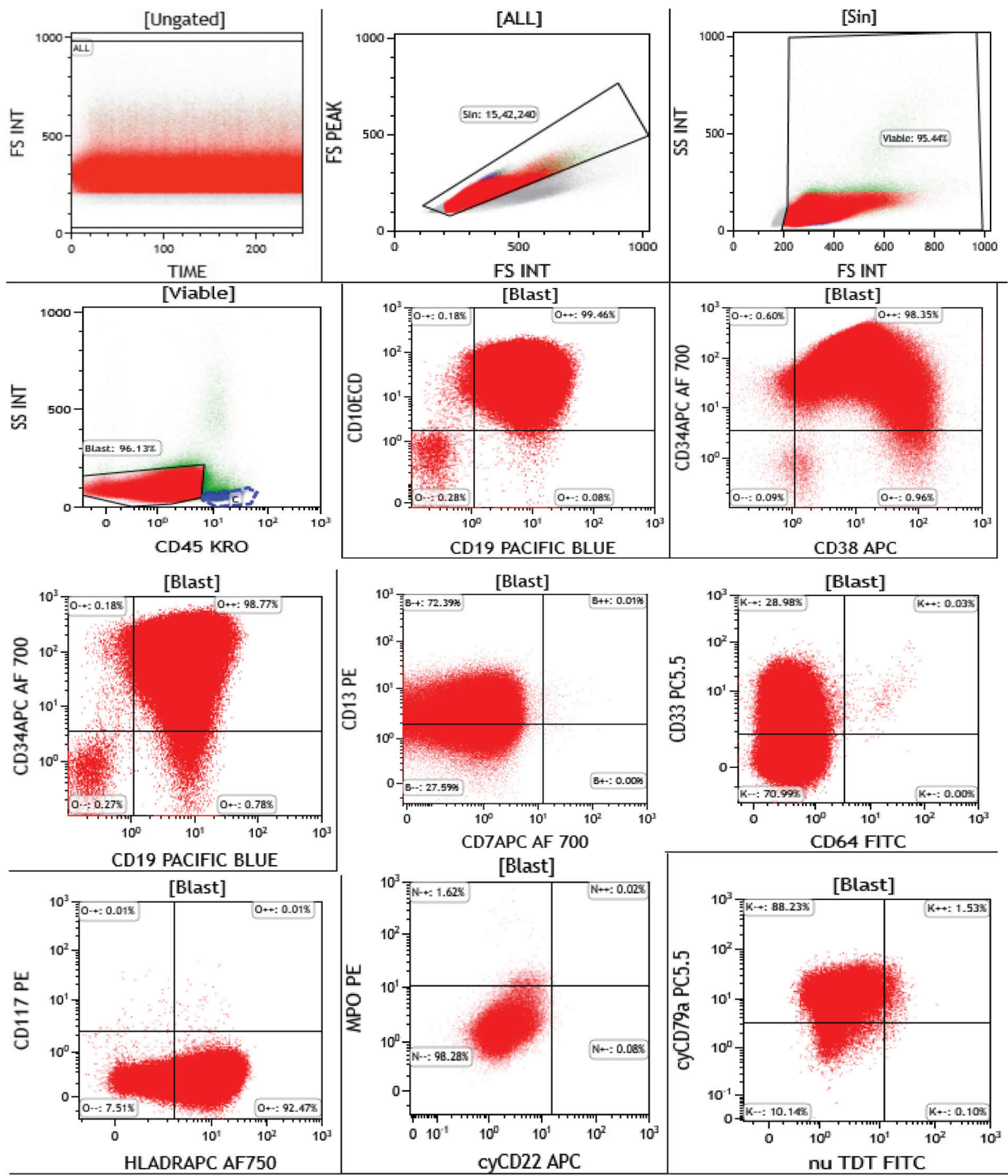

Figure 1. Flow cytometric immunophenotyping of newly diagnosed adult B-cell precursor acute lymphoblastic leukemia (BCP-ALL) patients harboring the $B C R-A B L 1$ fusion transcript with expression of aberrant myeloid markers. The blasts were gated on plots of $C D 45$ versus side scatter (SS) (red populations) and were confirmed to be B-lineage blasts based on expression of B-lineage-associated markers (CD19, CD10, cytoplasmic CD79a). The gated blasts showed expression of myeloid-lineage associated markers (CD13 and CD33), which was considered aberrant expression of myeloid markers in cases of B-ALL. 
was observed in 1.93\% (9/464) adult and 0.57\% (3/522) pediatric cases, being significantly more frequent in adult cases $(p=0.0027)$. The $t(1 ; 19)$ (TCF3-PBX) fusion transcript was observed in 3.66\% (17/464) adult and 4.21\% (22/522) pediatric cases, being significantly more frequent in pediatric cases $(\mathrm{p}<0.0001)$. The $\mathrm{t}(12 ; 21)(E T V 6-R U N X 1)$ fusion transcript was observed in 1.07\% (5/464) adult and 8.81\% (46/522) pediatric cases, being significantly more frequent in pediatric cases $(p<0.0001)$. Representative chimeric transcripts in BCP-ALL are shown in Figures 2 and 3. The frequency of chimeric transcripts in adult and pediatric BCP-ALL cases is shown in Table 4.

\begin{tabular}{|c|c|}
\hline 1. & $\begin{array}{l}\text { t(9;22)(BCR-ABL1) (p210 kDa) b2a2: } \\
\text { BCR-5'-ACAGAATTCCGCTGACCATCAATAAG-3' } \\
\text { ABL-5'-TGTTGACTGGCGTGATGTAGTGCTTGG-3' }\end{array}$ \\
\hline 2. & $\begin{array}{l}\text { t(9;22)(BCR-ABL1) (p210 kDa) b3a2: } \\
\text { BCR-5'-ACAGAATTCCGCTGACCATCAATAAG-3' } \\
\text { ABL-5'-TGTGACTGGCGTGATGTAGTGVITGG-3' }\end{array}$ \\
\hline 3. & $\begin{array}{l}(9 ; 22)(B C R-A B L 1) \text { (p230 kDa) e19a2: } \\
\text { BCR-5'-GAAGAAGTGTTCAGAAGCTCTCCC-3' } \\
\text { ABL-5'-TGTGATATAGCCTAAGACCCGGAG-3' }\end{array}$ \\
\hline
\end{tabular}

\section{Flow Cytometric Immunophenotyping Results}

Aberrant expression of myeloid markers CD13, CD33, and CD117 was significantly more frequent in adults compared to the pediatric group $(\mathrm{p}<0.0001)$ (Table 3$)$. Immunophenotypic aberrancies of myeloid markers including CD13, CD33, and CD117 in BCP-ALL cases with various genetic subtypes are shown in Table 4. Aberrant expression of CD13, CD33, and CD117 in adults with the $B C R-A B L 1$ minor (e1a2) transcript was observed in $31.88 \%, 28.98 \%$, and $1.44 \%$ of cases, respectively. In pediatric cases with the $B C R-A B L 1$ minor (e1a2) transcript, aberrant expression of CD13, CD33, and CD117 was observed in $22.72 \%, 18.18 \%$, and $4.54 \%$ of cases, respectively. Aberrant expression of CD13, CD33, and CD117 in adults with the $B C R-A B L 1$ major (b2a2) transcript was observed in $28.94 \%$, $7.7 \%$, and $2.6 \%$ of cases. On the other hand, aberrant expression of CD13, CD33, and CD117 was observed in $18.18 \%, 18.18 \%$, and $9.09 \%$ of pediatric cases with the BCR-ABL1 major (b2a2) transcript. Aberrant expression of CD13, CD33, and CD117 in adults with the $B C R-A B L 1$ major (b3a2) transcript was observed in $35 \%, 36.84 \%$, and $5 \%$ of cases. Aberrant expression of CD13 and CD33 was observed in 25\% and 25\% of pediatric cases with the $B C R-A B L 1$ major (b3a2) transcript, respectively. CD13 and CD33 myeloid markers were expressed significantly more frequently in adults with the $\mathrm{e} 1 \mathrm{a} 2$ and b2a2 transcripts (but not b3a2) compared to pediatric patients with these transcripts.

\begin{tabular}{|c|c|c|c|c|}
\hline Parameter & All cases $(n=986)$ & $\begin{array}{l}\text { Pediatric BCP-ALL cases, } \leq 12 \\
\text { years } \\
(n=522)\end{array}$ & $\begin{array}{l}\text { Adult BCP-ALL cases, }>12 \\
\text { years } \\
(n=464)\end{array}$ & $\mathbf{p}$ \\
\hline $\begin{array}{l}\text { Age (years) } \\
\text { Median } \\
\text { (minimum-maximum) }\end{array}$ & $\begin{array}{l}11 \\
(1-85)\end{array}$ & $\begin{array}{l}4 \\
(1-12)\end{array}$ & \begin{tabular}{|l}
26 \\
$(13-85)$ \\
\end{tabular} & **** \\
\hline $\begin{array}{l}\text { Age groups } \\
\leq 12 \text { years } \\
>12 \text { years }\end{array}$ & $\begin{array}{l}52.94 \% \text { (522/986) } \\
47.05 \% \text { (464/986) } \\
\end{array}$ & $52.94 \%$ (522/986) & $47.05 \%$ (464/986) & \\
\hline Males, n (\%) & \begin{tabular}{|l|l}
$61.86 \%$ \\
$(610 / 986)$
\end{tabular} & $63.79 \%$ (333/522) & $59.69 \%$ (277/464) & **** \\
\hline Females, n (\%) & 38.13\% (376/986) & $36.20 \%(189 / 522)$ & $40.30 \%$ (187/464) & **** \\
\hline $\begin{array}{l}\mathrm{Hb}, \mathrm{g} / \mathrm{L} \\
\text { Median } \\
\text { (minimum-maximum) }\end{array}$ & \begin{tabular}{|l|}
7.8 \\
$2.4-15.5$
\end{tabular} & $\begin{array}{l}8.37 \\
(3-15.2)\end{array}$ & \begin{tabular}{|l}
7.50 \\
$(2.4-15.5)$
\end{tabular} & **** \\
\hline $\begin{array}{l}\text { TLC, } \times 10^{9} / \mathrm{L} \\
\text { Median } \\
\text { (minimum-maximum) }\end{array}$ & \begin{tabular}{|l|}
12.4 \\
$0.3-576$
\end{tabular} & $\begin{array}{l}9.4 \\
(0.4-521)\end{array}$ & \begin{tabular}{|l}
19.4 \\
$(0.3-576)$
\end{tabular} & *** \\
\hline $\begin{array}{l}\text { Platelets, } \times 10^{9} / \mathrm{L} \\
\text { Median } \\
\text { (minimum-maximum) }\end{array}$ & \begin{tabular}{|l|}
27 \\
$1.3-703$
\end{tabular} & $\begin{array}{l}29 \\
(1.9-597)\end{array}$ & \begin{tabular}{|l}
24 \\
$(1.7-703)$
\end{tabular} & $\begin{array}{l}0.0046 \\
* *\end{array}$ \\
\hline CD13 & $20.58 \%$ (203/986) & $18.96 \%(99 / 522)$ & $22.41 \%(104 / 464)$ & $* * *$ \\
\hline CD33 & 18.66\% (184/986) & $13.02 \%(68 / 522)$ & $25 \%(116 / 464)$ & $* * *$ \\
\hline CD117 & $3.34 \%$ (33/986) & $3.44 \%(18 / 522)$ & $3.23 \%(15 / 464)$ & *** \\
\hline
\end{tabular}




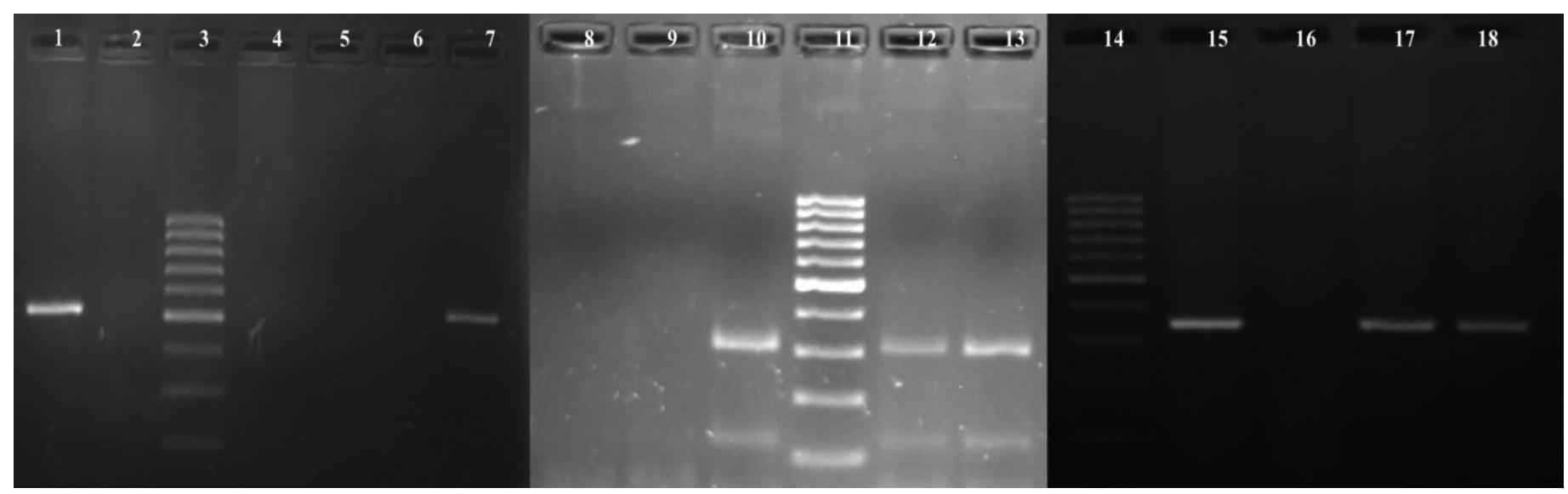

Figure 2. Multiplex assay showing presence of minor transcript (e1a2, p190 kDa) and major transcripts (b2a2, b3a2, p210 kDa) of BCR$A B L 1$ in adult BCP-ALL cases. Lane 1 shows minor transcript-positive control/internal reference genes (e1a2) (521 bp), lane 7 shows positive minor transcript in a patient, lane 10 shows major transcript-positive control/internal reference genes (b2a2) (310 bp), lanes 12 and 13 show positive major transcripts (b2a2) in two patients, lane 15 shows major transcript-positive control/internal reference genes (b3a2) (385 bp), and lanes 17 and 18 show positive major transcripts (b3a2) in two patients.
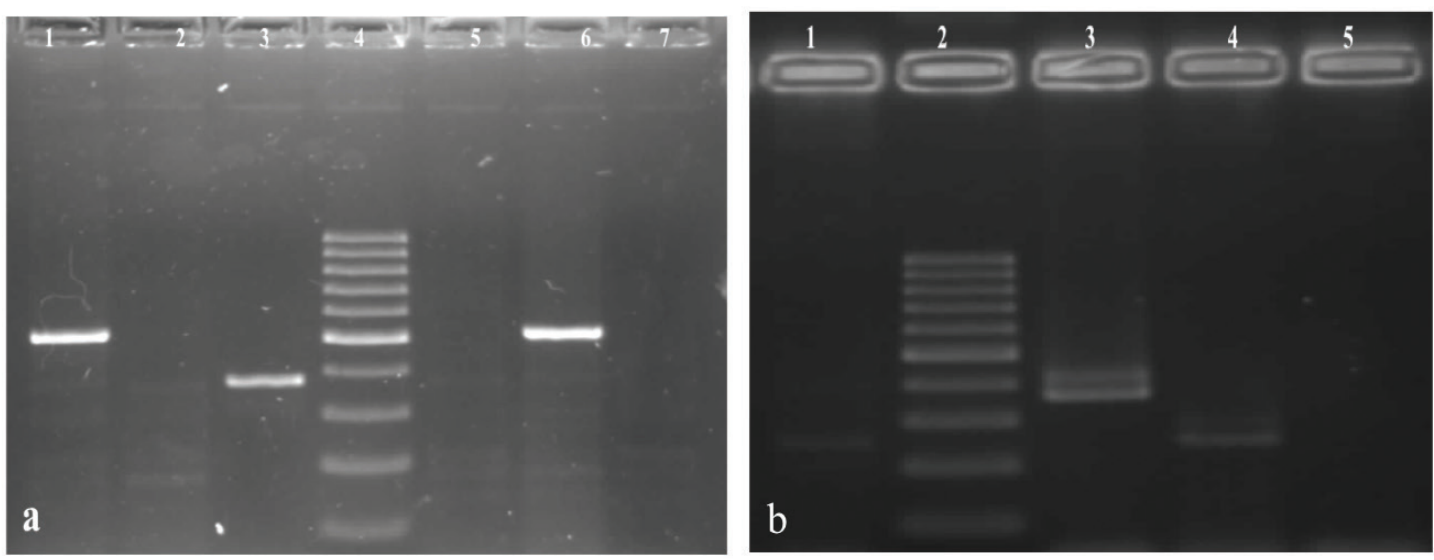

Figure 3. Multiplex assay showing presence of $t(4: 11), t(1: 19)$, and $t(12: 21)$ in adult BCP-ALL cases. Lane 1 of panel a shows $t(4: 11)$ (KMT2A-AF4)-positive control/internal reference genes (511 bp), lane 6 shows positive $\mathrm{t}(4: 11)(K M T 2 A-A F 4)$, and lane 3 shows $\mathrm{t}(1: 19)$ (373 bp) in patients. Lane 1 of panel b shows t(12;21)(ETV6-RUNX1)-positive control/internal reference genes, lane 3 shows $t(1: 19)(T C F 3-$ $P B X 1)$-positive control/internal reference genes, and lane 4 shows $t(12 ; 21)(E T V 6-R U N X 1)$ (373 bp) transcripts.

In patients with the $\mathrm{t}(12 ; 21)(E T V 6-R U N X 1)$ transcript, aberrant expression of CD13 and CD33 was observed in 40\% and 20\% of adult cases. Aberrant expression of CD13, CD33, and CD117 was respectively observed in $39.13 \%, 36.95 \%$, and $8.69 \%$ of pediatric cases with the $t(12 ; 21)(E T V 6-R U N X 1)$ transcript. In patients with the $\mathrm{t}(1: 19)(T C F 3-P B X 1)$ transcript, aberrant expression of CD13 and CD33 was observed in 5.88\% and 5.88\% of adult cases. Aberrant expression of CD13 was observed in 13.63\% of pediatric cases with the $\mathrm{t}(1: 19)$ (TCF3-PBX1) transcript. In patients with the $\mathrm{t}(4 ; 11)(K T M 2 A-A F 4)$ transcript, no aberrant myeloid marker expression was observed in adult or pediatric cases. Expression of CD13 and CD33 myeloid markers was not significantly different in adult cases with $\mathrm{t}(12 ; 21)(E T V 6-R U N X 1)$, $\mathrm{t}(1: 19)($ TCF3-PBX1), or $\mathrm{t}(4 ; 11)($ KTM2A-AF4) transcripts compared to pediatric BCP-ALL cases with these transcripts. Clinical and biological characteristics of patients harboring chimeric fusion transcripts and aberrant expressions of myeloid markers in adult and pediatric BCP-ALL cases are shown in Tables 5 and 6.

\section{Discussion}

Among 986 patients with BCP-ALL, the overall incidence of four fusion transcripts was found to be $38.36 \%$ in adults and $20.68 \%$ in pediatric cases. Table 7 compares several studies from India as well as research from Western countries, showing a high incidence of $\mathrm{t}(12 ; 21)(E T V 6-R U N X 1)$ (range: 7\%-34.4\%) and low incidence of the $t(9 ; 22)(B C R-A B L 1)$ fusion transcript (range: $2 \%-7.3 \%)$ in pediatric B-ALL cases $[9,10,11,12,14,15,16,19,21]$. 


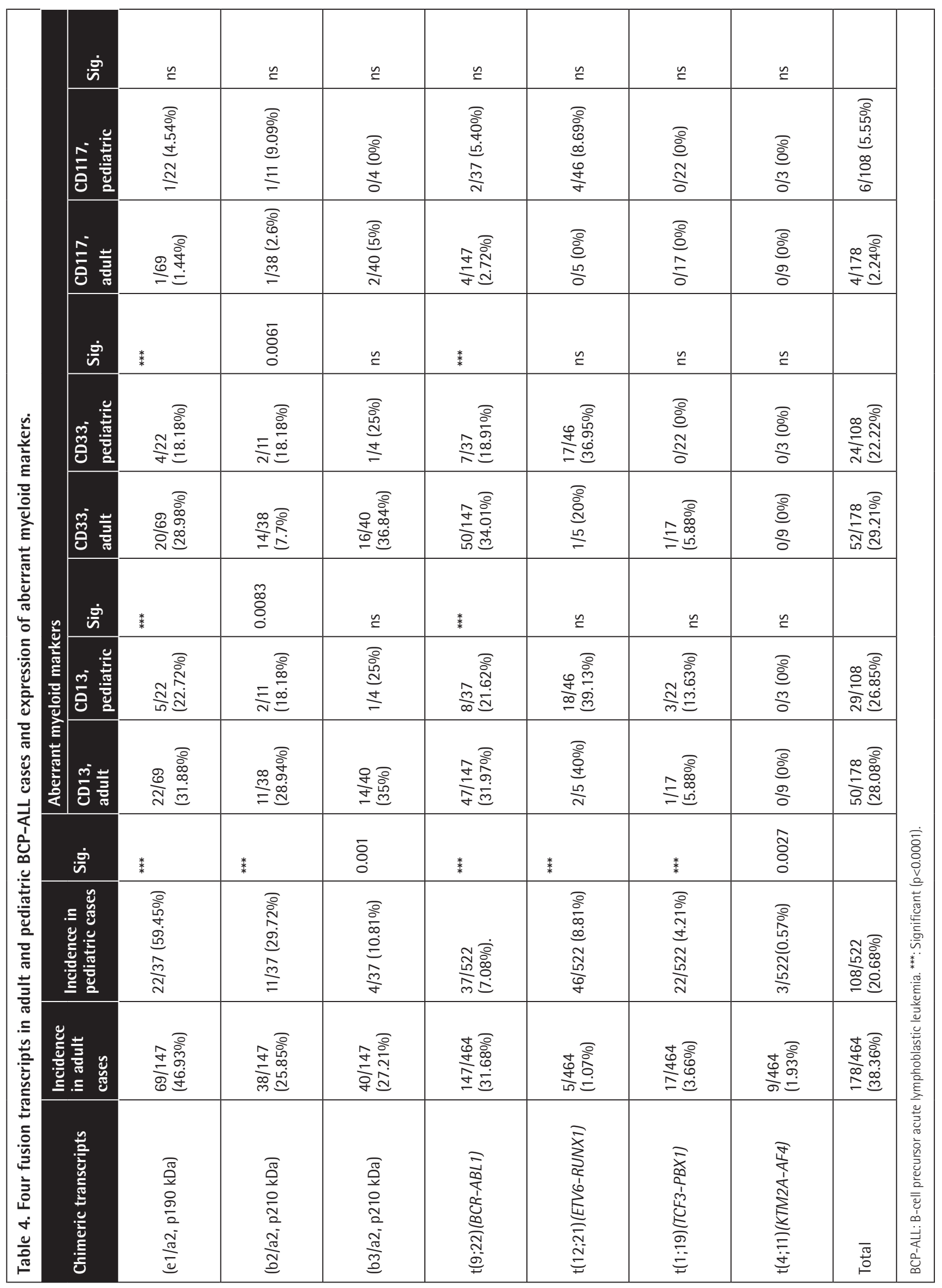




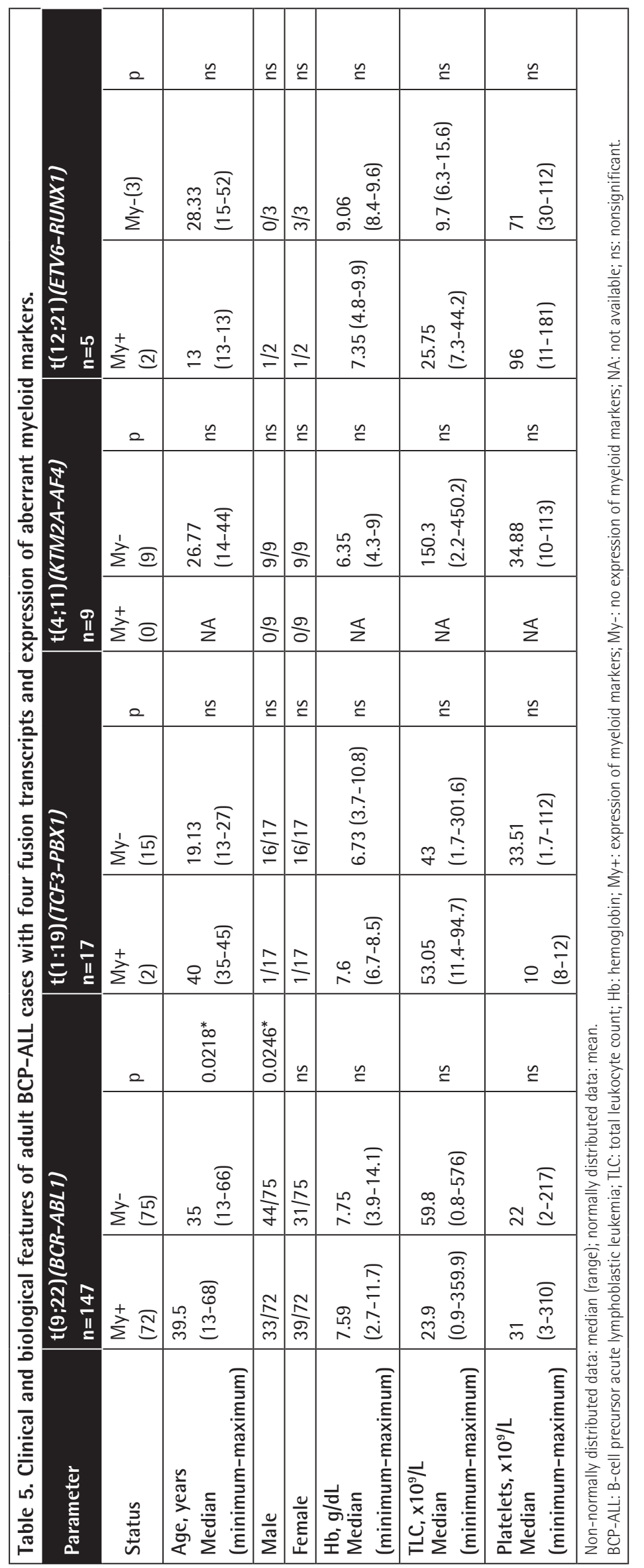

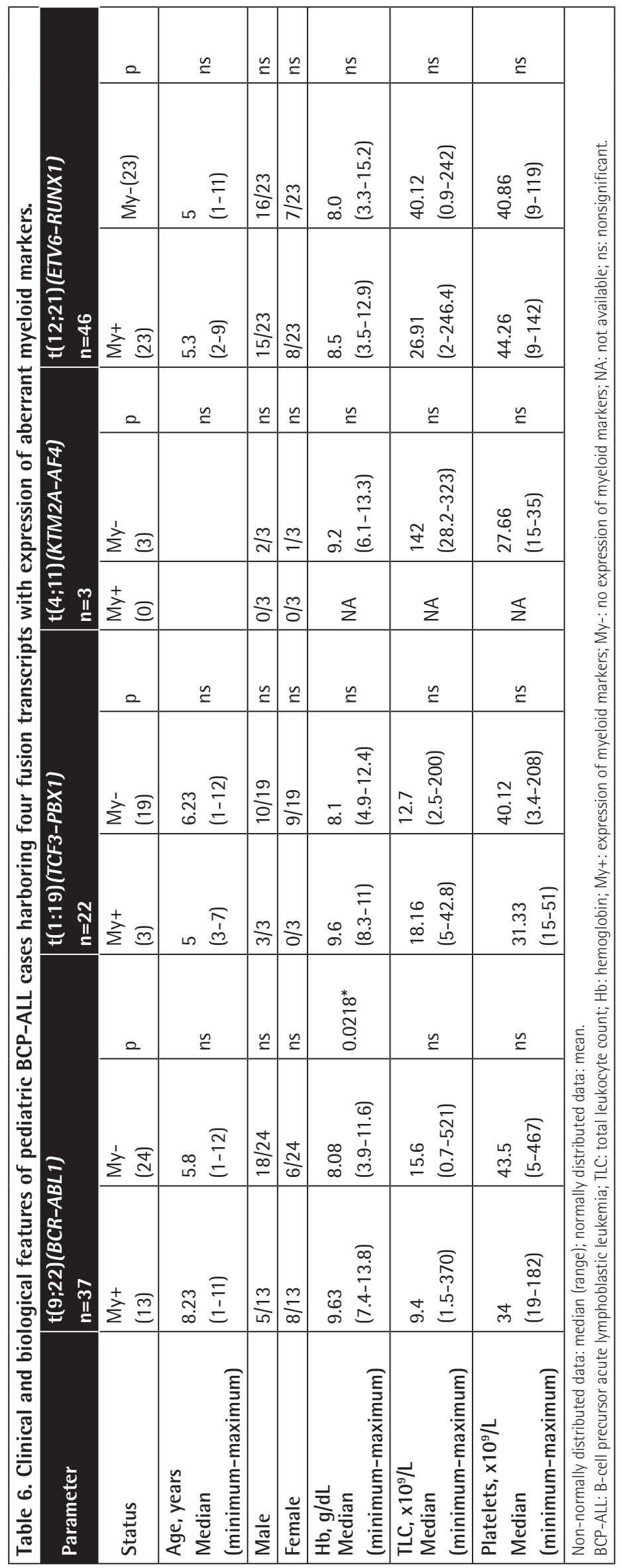


A comparison of several such studies of adult B-ALLs from India and Western countries is shown in Table 8 . The reported range of incidence of $\mathrm{t}(9 ; 22)(B C R-A B L 1)$ was $3.2 \%-37 \%$, that of $\mathrm{t}(1: 19)$ (E2A-PBX1) was $2.56 \%-6.25 \%$, that of $\mathrm{t}(4: 11)(K M T 2 A-A F 4)$ was 0\%-4.2\%, and that of $\mathrm{t}(12 ; 21)(E T V 6-R U N X 1)$ was $0 \%-14.9 \%$ $[8,9,11,13,16,19,20]$. Our RT-PCR findings in pediatric and adult BCP-ALL cases align well with these earlier studies. However, the e1a2 and b2a2 fusion transcripts were significantly more frequent in pediatric BCP-ALL cases whereas b3a2 fusion transcripts were significantly more frequent in adult BCP-ALL cases $(p<0.0001)$, a finding that has not been described in detail in earlier studies.

Myeloid-associated markers such as CD13, CD33, and CD117 were the most frequent immunophenotypic aberrancies among BCP-ALL patients with chimeric fusion transcripts (Figure 3). Several studies have shown the presence of myeloid-lineage specific markers in B-lineage ALL cases from India and from Western nations, without or with information regarding genetic subtypes. Gupta et al. [24], from Rohtak, India, reported CD13 expression in 50\%, CD33 in 2.6\%, and CD117 in 5.3\% of 38 B-ALL cases. Sharma et al. [18] from our institute reviewed 303 ALL cases and reported CD33 expression in $26.2 \%$ of pediatric and $32.9 \%$ of adult B-ALL cases, CD13 expression in 32.9\% of pediatric and $34.5 \%$ of adult B-ALL cases, and CD117 expression in $16.3 \%$ of pediatric and $22 \%$ of adult B-ALL cases. Den Boer et al. [22] from the Netherlands reported the expression of myeloid markers in $37.06 \%$ of 143 pediatric B-ALL cases. Seegmiller et al. from the United States examined 200 B-ALL cases and reported CD33 expression in $40.2 \%$ of pediatric and $49 \%$ of adult, CD13 expression in 56.1\% of pediatric and 51\% of adult, and CD117 expression in $0 \%$ of pediatric and 1\% of adult cases [25]. Supriyadi et al. [26] from Indonesia reported CD13 expression in 21\%, CD33 in 10\%, and CD117 in 4\% of 239 childhood B-ALL cases. Gujral et al. [23] from Mumbai, India, examined 1120 B-ALL cases and reported CD13 expression in $5.88 \%$, CD33 expression in $2.47 \%$, and CD117 expression in $0.68 \%$ of 1054 CALLA-positive ALL cases; CD13 expression in $10 \%$, CD33 expression in 20\%, and CD117 expression in 0\% of $10 \mathrm{Ph}$-positive B-ALL cases; CD13 expression in 50\%, CD33

Table 7. Comparison of incidence of $\mathrm{t}(9: 22)(B C R-A B L 1)$ and $\mathrm{t}(12: 21)(E T V 6-R U N X 1)$ in pediatric B-ALL cases as reported from India and other countries.

\begin{tabular}{|l|l|l|l|}
\hline Authors, year [Ref.] & $\mathbf{t}(\mathbf{9} ; 22)(B C R-A B L 1)$ & $\mathbf{t}(12 ; 21)(E T V 6-R U N X 1)$ & Country \\
\hline Borkhardt et al. [10] & - & $18.9 \%(63 / 334)$ & Italy \\
\hline Trka et al. [21] & - & $34.4 \%(15 / 54)$ & Czech Republic \\
\hline Liang et al. [15] & $6 \%(9 / 165)$ & $18 \%(30 / 165)$ & Taiwan \\
\hline Siraj et al. [19] & $5 \%(14 / 259)$ & $7 \%(18 / 259)$ & India \\
\hline Chung et al. [12] & - & $17.1 \%(21 / 123)$ & Korea \\
\hline Bhatia et al. [9] & $5.35 \%(3 / 56)$ & $16 \%(9 / 56)$ & India \\
\hline Martinez-Mancilla et al. [16] & $7.3 \%(19 / 261)$ & $14.9 \%(39 / 261)$ & Mexico \\
\hline Kerketta et al. [14] & $2.2 \%(2 / 90)$ & $28 \%(25 / 90)$ & India \\
\hline Chopra et al. [11] & $11.9 \%(26 / 218)$ & $7.3 \%(16 / 218)$ & India \\
\hline Present study & $7.08 \%(37 / 522)$ & $8.81 \%(46 / 522)$ & India \\
\hline B-ALL: B-cell acute Iymphoblastic leukemia. & & & \\
\hline
\end{tabular}

Table 8. Comparison of incidence of four fusion transcripts in adult B-ALL cases as reported from India and other countries.

\begin{tabular}{|c|c|c|c|c|c|}
\hline Authors, year [Ref.] & $\mathrm{t}(9 ; 22)(B C R-A B L 1)$ & $\mathrm{t}(12 ; 21)(E T V 6-R U N X 1)$ & $\mathrm{t}(1: 19)(T C F 3-P B X 1)$ & $\mathrm{t}(4: 11)(K M 2 T A-A F 4)$ & Country \\
\hline Bao et al. [8] & $37 \%(47 / 127)$ & - & - & $3.14 \%(4 / 127)$ & China \\
\hline Sudhakar et al. [20] & $3.2 \%(2 / 64)$ & $6.25 \%(4 / 64)$ & $6.25 \%(4 / 64)$ & $1.56 \%(1 / 64)$ & India \\
\hline Bhatia et al. [9] & $25.64 \%(10 / 39)$ & $5.12 \%(2 / 39)$ & $2.56 \%(1 / 39)$ & $2.56 \%(1 / 39)$ & India \\
\hline $\begin{array}{l}\text { Martinez-Mancilla et } \\
\text { al. [16] }\end{array}$ & $7.3 \%(19 / 261)$ & $14.9 \%(39 / 261)$ & $5.8 \%(15 / 261)$ & $4.2 \%(11 / 261)$ & Mexico \\
\hline Gupta et al. [13] & $\begin{array}{l}8.8 \%(22 / 249 ;(169 \\
\text { pediatric, } 104 \text { adult) }\end{array}$ & $5.5 \%(15 / 270)$ & Not done & Not done & India \\
\hline Present study & $31.68 \%(147 / 464)$ & $1.07 \%(5 / 464)$ & $3.66 \%(17 / 464)$ & $1.93 \%(9 / 464)$ & India \\
\hline
\end{tabular}


expression in 0\%, and CD117 expression in 0\% of 2 KMT2Arearranged B-ALL cases; and CD13, CD33, and CD117 expression in none of 4 ETV6-RUNX1-rearranged B-ALL cases. Gupta et al. [13] from Kolkata, India, reported CD13 expression in 40.9\%, CD33 expression in $36.9 \%$, and co-expression of CD13/CD33 in $22 \mathrm{Ph}$-positive patients from among 273 (169 pediatric and 104 adult) B-ALL cases. CD13 was the most frequent aberrantly expressed marker $(73.3 \%, 11 / 15)$ among the 5.5\% (15/270) of patients with $t(12 ; 21)$ detected by fluorescence in situ hybridization.

In summary, the authors referenced above evaluated from 38 to 1120 B-ALL cases in their respective studies, reporting aberrant expression of CD13 in 5.88\%-56.1\%, CD33 in 2.47\%-49\%, and CD117 in 0.68\%-22\% of those B-ALL cases. As shown in Table 9, aberrant immunophenotypes in the context of multiple genetic abnormalities have been analyzed by only a few authors, including Gupta et al. [13] [22 Ph-positive patients and 15 patients with $\mathrm{t}(12 ; 21)]$ and Gujral et al. [23] (10 Ph-positive, 2 KMT2A-rearranged, and 4 ETV6-RUNX1-rearranged B-ALL cases). However, the numbers of their patients with specific genetic abnormalities are very small compared to our study cohort (Table 9).

Among our adult BCP-ALL cases, the incidence of chimeric fusion transcripts was $38.36 \%$, with aberrant myeloid-associated marker CD13 expressed in 28.08\%, CD33 in 29.21\%, and CD117 in 2.24\% of cases (Table 4). Furthermore, we also observed that adult patients harboring $B C R-A B L 1$ fusion transcripts and expressing aberrant myeloid markers were significantly older at presentation $(p=0.0218)$ with male preponderance $(p=0.0246)$. We tested the age factor (continuous variable) for significance in males and females separately, not together. In the case of male patients, we found age to be significant, but not so in female patients.
Our adult patients with $t(9 ; 22)(B C R-A B L 1)$ fusion transcripts showed the highest incidence of aberrant expression of myeloid markers with CD13 in 31.97\%, CD33 in 34.01\%, and CD117 in $2.72 \%$ of cases. In pediatric BCP-ALL cases, the incidence of chimeric fusion transcripts was 20.68\% with aberrant expression of CD13 observed in $26.85 \%$, CD33 in 22.22\%, and CD117 in 5.55\% of cases. Pediatric patients with $\mathrm{t}(12 ; 21)$ (ETV6-RUNX1) fusion transcripts showed the highest incidence of aberrant myeloid marker expression with CD13 in 39.13\%, CD33 in 36.95\%, and CD117 in 8.69\% of cases. Among adult and pediatric BCP-ALL cases with $\mathrm{t}(12 ; 21)(E T V 6-R U N X 1), \mathrm{t}(1: 19)$ (TCF3-PBX1), and $\mathrm{t}(4 ; 11)(K T M 2 A-A F 4)$ transcripts, the incidence of expression of $\mathrm{CD} 13$ and $\mathrm{CD} 33$ myeloid markers was not significantly different.

\section{Study Limitations}

Our observations of a large cohort of BCP-ALL cases have further expanded the knowledge of the complex interrelationships among genetic subtypes and immunophenotypic aberrancies. However, we studied the relationships between only four specific chimeric fusion transcripts and expressions of myeloid markers in this large cohort of BCP-ALL patients. In the future, we plan to study a wider spectrum of genetic/molecular abnormalities including $B C R-A B L 1$-like $A L L$ in relation to immunophenotypic aberrancies in BCP-ALL patients.

\section{Conclusion}

$\mathrm{t}(9 ; 22)(B C R-A B L 1)$ and $\mathrm{t}(12: 21)(E T V 6-R U N X 1)$ were the most frequent chimeric fusion transcripts seen in our adult and pediatric B-ALL cases, respectively. Aberrant expression of CD13, CD33, and CD117 myeloid markers was significantly more frequent in adults compared to the pediatric group $(p<0.0001)$. The $\mathrm{e} 1 \mathrm{a} 2$ and b2a2 fusion transcripts were significantly more frequent in pediatric BCP-ALL cases, whereas b3a2

\begin{tabular}{|c|c|c|c|c|c|}
\hline Authors, year [Ref.] & $\mathrm{t}(9 ; 22)(B C R-A B L 1)$ & $\mathrm{t}(12 ; 21)(E T V 6-R U N X 1)$ & $\mathrm{t}(1: 19)(T C F 3-P B X 1)$ & $\mathrm{t}(4: 11)(K M 2 T A-A F 4)$ & Country \\
\hline Borkhardt et al. [10] & Not mentioned & $\begin{array}{l}18.9 \%(63 / 334 \text { pediatric } \\
\text { patients) }\end{array}$ & Not mentioned & Not mentioned & Italy \\
\hline Gupta et al. [13] & $\begin{array}{l}8.8 \%(22 / 249 ; 169 \\
\text { pediatric, } 104 \text { adult })\end{array}$ & $5.5 \%(15 / 270)$ & Not done & Not done & India \\
\hline Raiya et al. [29] & $\begin{array}{l}24 \%(32 / 130 ; 68 \\
\text { pediatric, } 62 \text { adult })\end{array}$ & Not done & Not done & Not done & India \\
\hline $\begin{array}{l}\text { Present study, adult } \\
\text { patients }\end{array}$ & $31.68 \%(147 / 464)$ & $1.07 \%(5 / 464)$ & $3.66 \%(17 / 464)$ & $1.93 \%(9 / 464)$ & \\
\hline
\end{tabular}


fusion transcripts were significantly more frequent in adult BCP-ALL cases, an observation not documented previously in the literature to the best of our knowledge.

Expression of CD13 and CD33 markers was significantly more frequent in adults with e1a2 and b2a2 transcripts (but not b3a2) compared to pediatric patients harboring those transcripts. Aberrant myeloid CD markers can be used to predict chimeric fusion transcripts at baseline, helping to plan appropriate tyrosine kinase inhibitor therapy for BCP-ALL patients with specific chimeric fusion transcripts. The incidence of expression of CD13 and CD33 markers was not significantly different in adult patients with $\mathrm{t}(12 ; 21)(E T V 6-R U N X 1), \mathrm{t}(1: 19)(T C F 3-P B X 1)$, and $\mathrm{t}(4 ; 11)($ KTM2A-AF4) transcripts compared to pediatric BCP-ALL patients with those transcripts. Very few studies to date have described such findings in detail.

\section{Acknowledgments}

This work wassupported bya grant(No. 71/2-Edu-16/937/18/03/2019) from the Postgraduate Institute of Medical Education and Research (PGIMER), Chandigarh, India. Special thanks to the Indian Council of Medical Education and Research for providing a Junior Research Fellowship to D.G.G.

\section{Ethics}

Ethics Committee Approval: The institutional research committee approved the study (number: INT/IEC/2017/191, dated: 23 August 2017). All experiments or tests performed involving human subjects were conducted according to institutional ethical standards and the Declaration of Helsinki.

Informed Consent: Samples of 2-3 $\mathrm{mL}$ of aspirated bone marrow and 3-5 $\mathrm{mL}$ of peripheral blood were collected in EDTAcoated vials after obtaining the signature of the patient or the patient's guardian on an informed consent form as approved by the Human Institutional Ethics Committee of PGIMER.

\section{Authorship Contributions}

Concept: D.G.G., N.V.; Design: D.G.G., N.V.; Data Collection or Processing: D.G.G., J.B., P.B., M.G., P.S., P.R.; Supervision: P.M., A.T., A.K., S.V.; Analysis or Interpretation: D.G.G., N.V., A.K.; Literature Search: D.G.G., N.V.; Writing: D.G.G., N.V., S.N., M.U.S.S.

Conflict of Interest: No conflict of interest was declared by the authors.

Financial Disclosure: The authors declared that this study received no financial support.

\section{References}

1. Dias A, Kenderian SJ, Westin GF, Litzow MR. Novel therapeutic strategies in acute lymphoblastic leukemia. Curr Hematol Malig Rep 2016;11:253-264.

2. Egler RA, Ahuja SP, Matloub Y. L-Asparaginase in the treatment of patients with acute lymphoblastic leukemia. J Pharmacol Pharmacother 2016;7:62-71.
3. Mullighan CG. The genomic landscape of acute lymphoblastic leukemia in children and young adults. Hematology Am Soc Hematol Educ Program 2014;2014:174-180.

4. Roberts KG, Li Y, Payne-Turner D, Harvey RC, Yang YL, Pei D, McCastlain K, Ding L, Lu C, Song G, Ma J, Becksfort J, Rusch M, Chen SC, Easton J, Cheng J, Boggs K, Santiago-Morales N, lacobucci I, Fulton RS, Wen J, Valentine M, Cheng C, Paugh SW, Devidas M, Chen IM, Reshmi S, Smith A, Hedlund E, Gupta P, Nagahawatte P, Wu G, Chen X, Yergeau D, Vadodaria B, Mulder H, Winick NJ, Larsen EC, Carroll WL, Heerema NA, Carroll AJ, Grayson G, Tasian SK, Moore AS, Keller F, Frei-Jones M, Whitlock JA, Raetz EA, White DL, Hughes TP, Guidry Auvil JM, Smith MA, Marcucci G, Bloomfield CD, Mrózek K, Kohlschmidt J, Stock W, Kornblau SM, Konopleva M, Paietta E, Pui CH, Jeha S, Relling MV, Evans WE, Gerhard DS, Gastier-Foster JM, Mardis E, Wilson RK, Loh ML, Downing JR, Hunger SP, Willman CL, Zhang J, Mullighan CG. Targetable kinase-activating lesions in Ph-like acute lymphoblastic leukemia. N Engl J Med 2014;371:1005-1015.

5. Wang N, Huang L, Wang D, Wang J, Jiang L, Zhou K, Yang Y, Xu D, Zhou J. Successful engraftment of human acute lymphoblastic leukemia cells in NOD/SCID mice via intrasplenic inoculation. Cancer Biol Ther 2012;13:11581164.

6. Chiaretti S, Gianfelici V, O'Brien SM, Mullighan CG. Advances in the genetics and therapy of acute lymphoblastic leukemia. Am Soc Clin Oncol Educ Book 2016;35:e314-322.

7. Stock W. Adolescents and young adults with acute lymphoblastic leukemia. Hematology Am Soc Hematol Educ Program 2010;2010:21-29.

8. Bao L, Gross SA, Ryder J, Wang X, Ji M, Chen Y, Yang Y, Zhu S, Irons RD. Adult precursor B lymphoblastic leukemia in Shanghai, China: characterization of phenotype, cytogenetics and outcome for 137 consecutive cases. Int J Hematol 2009;89:431-437.

9. Bhatia P, Binota J, Varma N, Bansal D, Trehan A, Marwaha RK, Malhotra $\mathrm{P}$, Varma S. Incidence of common chimeric fusion transcripts in B-cell acute lymphoblastic leukemia: an Indian perspective. Acta Haematol 2012:128:17-19.

10. Borkhardt A, Cazzaniga G, Viehmann S, Valsecchi MG, Ludwig WD, Burci L, Mangioni S, Schrappe M, Riehm H, Lampert F, Basso G, Masera G, Harbott J, Biondi A. Incidence and clinical relevance of TEL/AML1 fusion genes in children with acute lymphoblastic leukemia enrolled in the German and Italian multicenter therapy trials. Associazione Italiana Ematologia Oncologia Pediatrica and the Berlin-Frankfurt-Münster Study Group. Blood 1997;15;90:571-577.

11. Chopra A, Soni $S$, Verma $D$, Kumar D, Dwivedi $R$, Vishwanathan $A$, Vishwakama G, Bakhshi S, Seth R, Gogia A, Kumar L, Kumar R. Prevalence of common fusion transcripts in acute lymphoblastic leukemia: a report of 304 cases. Asia Pac J Clin Oncol 2015;11:293-298.

12. Chung HY, Kim KH, Jun KR, Jang S, Park CJ, Chi HS, Im HJ, Seo JJ, Seo EJ. Prognostic significance of TEL/AML1 rearrangement and its additional genetic changes in Korean childhood precursor B-acute lymphoblastic leukemia. Korean J Lab Med 2010;30:1-8.

13. Gupta N, Pawar R, Banerjee $S$, Brahma $S$, Rath A, Shewale $S$, Parihar $M$, Singh $M$, Arun SR, Krishnan S, Bhatacharyya A, Das A, Kumar J, Bhave S, Radhakrishnan V, Nair R, Chandy M, Arora N, Mishra D. Spectrum and immunophenotypic profile of acute leukemia: a tertiary center flow cytometry experience. Mediterr J Hematol Infect Dis 2019;11:e2019017.

14. Kerketta LS, Rao VB, Ghosh K. Chimeric fusion karyotypes in childhood B-cell acute lymphoblastic leukemia. Indian Pediatr 2014;51:152-153.

15. Liang DC, Shih LY, Yang CP, Hung IJ, Chen SH, Jaing TH, Liu HC, Chang WH. Multiplex RT-PCR assay for the detection of major fusion transcripts in Taiwanese children with B-lineage acute lymphoblastic leukemia. Med Pediatr Oncol 2002;39:12-17.

16. Martinez-Mancilla M, Rodriguez-Aguirre I, Tejocote-Romero I, MedinaSanson A, Ocadiz-Delgado R, Gariglio P. Clinical relevance of the 
fusion transcripts distribution pattern in mexican children with acute lymphoblastic leukemia. J Pediatr Hematol Oncol 2013;35:170-173.

17. Olarte-Carrillo I, Ramos-Peñafiel CO, Miranda-Peralta E, Mendoza-Salas I, Nacho-Vargas KA, Zamora-Domínguez JA, Mendoza-Garcia E, Rozen-Fuller E, Kassack-Ipiña JJ, Collazo-Jaloma J, Martínez-Tovar A. Frequency of the minor BCR-ABL $(\mathrm{e} 1 ; a 2)$ transcript oncogene in a Mexican population with adult acute lymphoblastic leukaemia. Revista Médica Del Hospital General De México 2015;78:119-123.

18. Sharma M, Sachdeva MU, Varma N, Varma S, Marwaha RK. Characterization of immunophenotypic aberrancies in adult and childhood acute lymphoblastic leukemia: a study from Northern India. J Cancer Res Ther 2016;12:620-626.

19. Siraj AK, Kamat $S$, Gutiérrez MI, Banavali S, Timpson G, Sazawal S, Bhargava M, Advani S, Adde M, Magrath I, Bhatia K. Frequencies of the major subgroups of precursor B-cell acute lymphoblastic leukemia in Indian children differ from the West. Leukemia 2003;17:1192-1193.

20. Sudhakar N, Rajalekshmy KR, Rajkumar T, Nancy KN. RT-PCR and real-time PCR analysis of E2A-PBX1, TEL-AML1, mBCR-ABL and KMT2A-AF4 fusion gene transcripts in de novo $B$-lineage acute lymphoblastic leukaemia patients in south India. J Genet 2011;90:349-353.

21. Trka J, Zuna J, Hrusák 0 , Kalinová $M$, Muzíková $K$, Lauschman $H$, Starý J. Impact of TEL/AML1-positive patients on age distribution of childhood acute lymphoblastic leukemia in Czech Republic. Pediatric Hematology Working Group in Czech Republic. Leukemia 1998;12:996-997.

22. Den Boer ML, Kapaun P, Pieters R, Kazemier KM, Janka-Schaub GE, Veerman AJ. Myeloid antigen co-expression in childhood acute lymphoblastic leukaemia: relationship with in vitro drug resistance. $\mathrm{Br} J$ Haematol 1999;105:876-882.
23. Gujral $S$, Badrinath $Y$, Kumar $A$, Subramanian $P G$, Raje $G$, Jain $H$, Pais $A$, Amre Kadam PS, Banavali SD, Arora B, Kumar P, Hari Menon VG, Kurkure PA, Parikh PM, Mahadik S, Chogule AB, Shinde SC, Nair CN. Immunophenotypic profile of acute leukemia: critical analysis and insights gained at a tertiary care center in India. Cytometry B Clin Cytom 2009;76:199-205.

24. Gupta M, Monga L, Mehrotra D, Chhabra S, Singhal S, Sen R. Immunophenotypic aberrancies in acute leukemia: a tertiary care centre experience. Oman Med J 2021;36:e218.

25. Seegmiller AC, Kroft SH, Karandikar NJ, McKenna RW. Characterization of immunophenotypic aberrancies in 200 cases of B acute lymphoblastic leukemia. Am J Clin Pathol 2009;132:940-949.

26. Supriyadi E, Veerman AJ, Sutaryo, Purwanto I, van de Ven PM, Cloos J. Myeloid antigen expression in childhood acute lymphoblastic leukemia and its relevance for clinical outcome in Indonesian ALL-2006 Protocol. J Oncol 2012;2012:135186.

27. Borowitz MJ, Chan JK, Downing JR, Le Beau MM, Arber DA. B-Lymphoblastic leukaemia/lymphoma with recurrent genetic abnormalities. In: Swerdlow SH, Campo E, Harris NL, Jaffe ES, Pileri SA, Stein H, Thiele J (eds). WHO Classification of Tumours of Haematopoietic and Lymphoid Tissues. 4th Edition. Geneva, World Health Organization, 2017.

28. Pakakasama $S$, Kajanachumpol $S$, Kanjanapongkul $S$, Sirachainan $N$, Meekaewkunchorn A, Ningsanond V, Hongeng S. Simple multiplex RT-PCR for identifying common fusion transcripts in childhood acute leukemia. Int J Lab Hematol 2008;30:286-291.

29. Raiya B, Vora H, Trivedi P, Parikh B. Flowcytometric analysis of leukemic blasts - as primary screening test for $B C R / A B L 1$ gene rearrangement in B-ALL. EJMO 2019;3:191-198. 